\title{
Fair use and fair competition for digitized cultural goods: the case of eBooks
}

\author{
Françoise Benhamou
}

Published online: 4 March 2015

(C) Springer Science+Business Media New York 2015

\begin{abstract}
This paper investigates the main characteristics of the eBook market at the beginning of the 2010s. Although just emerging in Europe, the eBook market is much more developed in the USA, thanks to the launch of the Amazon Kindle in 2007 in addition to other tablets. It argues that the peculiarities of the eBook market lead to unfair competition between internet giants (especially Google and Amazon) and publishers. The paper outlines the legal and economic tools put forward in order to justify economic strategies in this field: fair use in the case of Google, lower prices for consumers in the case of Amazon. The paper focuses explicitly on the boundaries of competition policies in order to raise fair competition for digitized cultural industries.
\end{abstract}

Keywords eBooks $\cdot$ Publishing industry $\cdot$ Fair use $\cdot$ Fair competition

\section{Introduction}

In spite of early experiences, like the ongoing Gutenberg project launched by Michael Hart in 1971, the emerging eBook market is less developed than comparable cultural markets in music, film and digitized press.

The development of the market depends on the level and quality of the users' equipment (in e-reading devices like tablets, readers, computers and phones).

Presidential address presented at the 18th International Conference on Cultural Economics, Association for Cultural Economics International, UQAM, Montreal, 27 June 2014.

F. Benhamou $(\bowtie)$

Autorité de régulation des communications électroniques et des postes (ARCEP) and Université

Paris 13, Villetaneuse, France

e-mail: fbenhamou5@gmail.com 
Consumers also require sufficient storage capacity and speed of information transmission (for enriched books including videos and music).

Digitization generates direct and indirect network externalities (David 1985; Shapiro and Varian 1998). Katz and Shapiro (1986) show that for many products, the utility that a user derives from consumption increases with the number of agents consuming the good. Moreover, a full range of content needs to be easily available. Catalogs and devices are complementary goods: When one of them becomes cheaper or of better quality, the market of the other extends. If more eBooks are available and if the depth and variety of catalogs increase, people buy more devices, and, reciprocally, the rise in demand for devices acts as an incentive to increase the number of eBooks that can be downloaded.

Consumers demand easy online payment systems and fair prices. Publishers have to take into account that buyers expect a significant price gap between books and eBooks. But they ignore the willingness to pay for the digital version of a book and a fortiori for enhanced contents. They cannot rely on the sole observation of early adopters' behavior.

In the USA, the market is booming: It represented $0.6 \%$ of the total trade market in 2008, $6.4 \%$ in 2010 and $22 \%$ in 2012. In 2012, eBook sales represented $\$ 3.04$ billion (Source: Bookstats 2013, American Publishers Ass.). Conversely, the market is narrow and still in its infancy in Europe: in 2012, it represented $12 \%$ of the UK's total book market ( $8 \%$ in 2011 and $5 \%$ in 2010), the equivalent of $£ 411$ million (Source: The Publishers Ass.). It is $<3 \%$ of the total market in France (source: $\mathrm{SNE}$, where publishers do not wish to destabilize the paper bookselling sector by launching eBooks at a discounted price.

This paper stresses the importance and the rise of giant actors, who try to organize the market following two different economic models: an open model (Google) and a lock-in model (Amazon, Apple). Whichever model on which they build their growth, these actors continuously strengthen their dominant position. Considering the history of this very recent market, we wonder whether legal tools and antitrust decisions are appropriate in order to curtail the risk of dominant positions being abused.

After a short review of the literature, this paper provides a description of the main characteristics of the market (2), addressing the effects of Google Books on the one side (3), and of Amazon's strategy on the other (4). It concludes with some questions about the future of regulation (5).

\section{Main characteristics of the eBook market}

Economic analysis of eBooks is still in its infancy. Economists focus on the digital publishing of scientific research issues (see among others McCabe and Snyder 2005). They analyze the economics of journals and emphasize the very controversial question of free access. They deal quite marginally with eBooks. Thompson (2012) provides a general view of the book market, and Wischenbart (2013) insists on different aspects of eBook economics. Most publications are a mix of insider tales and more serious analysis (see among others Merkovski 2013). Many papers 
discuss the existence of a 'long tail' effect as a source of added value for consumers (Brynjolfsson et al. 2003; Benghozi and Benhamou 2010; Moreau and Peltier 2012). Fair competition is studied by Law academics generally (see among others Manuel 2009).

How can we characterize the eBook market? Firstly, eBooks show both privategood and public-good characteristics: Readers can buy and download eBooks, but consumption remains non-rivalrous and, in some segments of the market, nonexcludable. Secondly, eBooks (and books as well) are experienced goods: Utility is unknown to consumers prior to consumption. Uniqueness goes hand in hand with oversupply and infinite variety, which implies a high level of uncertainty: It is the Nobody knows principle as stressed by Caves (2000).

\subsection{A disruptive innovation}

With eBooks, the publishing industry faces a disruptive innovation (Forge and Blackman 2009). The development of an eBook market leads to disintegration in the publishing value chain. Attention becomes the scarce resource (Simon 1971). The structure of costs changes drastically: some costs decrease strongly (printing, physical distribution), while new costs appear. At the same time, there is a deep trend toward print on demand, and a movement toward disintermediation, with the opportunity for publishers to sell books directly online, the possibility of selfpublication for authors, direct promotion through social networks and usergenerated criticism (i.e., Amazon recommendations).

To this day, growth in the digital segment has not compensated for the loss of revenue due to the migration from books to eBooks. Therefore, there has been a decrease in value. For example, in the first quarter of 2012, sales of mass-market paperbacks in the USA fell $20.8 \%$. This was due to a shift from printed to digital material for trade paperback sales (source: APA). Several stages disappear from the traditional value chain, especially printers and brick-and-mortar retailers. With the liquidation of the retail chain, Borders, in 2011, and many other retailers worldwide, including independent bookshops as well as bookselling chains, we see that the existence of retailers is jeopardized. With net margins of 2-3\% in France, for example (Gallimard 2007), small independent bookshops are deeply threatened by changes in the book market. Doubts are rising concerning the extent to which independent bookshops and brick and mortar will survive eBook market development.

However, in such a context, there is no evidence of a sustainable new model (except in the case of academic and scientific segments-Dewatripont et al. 2006). Even if a long tail effect exists, it does not compensate for losses (Benhamou 2014). Moreover, the rise in piracy is an issue for publishers-even if its impact is debatable (MOTif 2012).

The field is now wide open for new entrants. On the one side, giants (e-commerce, telecom and computer companies), and on the other, pure player micro-firms enter the market. Vertical concentration (for example, Amazon is a retailer and a publisher) creates a new balance of power between publishers and authors, who fear a strong decrease in revenue. 
For giants, two alternative models coexist depending on the format. Google has adopted an open format in the framework of a classical double-sided market (Rochet and Tirole 2003): eBooks are a tool for online direct or indirect advertising, through the collection of personal data. The economic models of Amazon and Apple rely on the lock-in of users, in the framework of a proprietary format. For Amazon, books and eBooks are a part of more general e-commerce activity. Initially, Amazon's Kindle files could be read on the Kindle only. For Apple, eBooks are seen as an additional application within the general economic model of Apple. Apple has restricted its iBook files to the iPad (and iPhone). Even when it is possible to download a file on another device, users stay in the Amazon/Apple ecosystems of software and services.

\section{Google, fair use and eBooks}

The Google Library Project (Google Books) was launched in 2004. Google scans, converts and stores millions of books thanks to agreements with public libraries: New York Public Library, Harvard, Stanford, and Michigan University libraries in the USA, the Bodleian at Oxford University in the UK, and the Bibliothèque municipale of Lyon, France. By early 2011, Google had proceeded to digitize 15 million books, making text-mining possible on a massive scale (ParisTech Review 2011).

The business model consists of free access, advertising, indirect revenues due to an increase in traffic, exploitation of personal data and a broadening of Google's panel of services.

\subsection{A series of law cases}

During the autumn of 2005, a group of authors and publishers filed a class action against Google, alleging copyright violation. ${ }^{1}$ Google argued that scans of copyrighted works were based on fair use (or use that does not require authorization by the copyright holder). In 2008, after lengthy negotiations, the parties agreed on a settlement. Google would continue to make books in the public domain available for users to read, download and print, free of charge. For works under copyright protection, Google would pay $\$ 45 \mathrm{M}$ to compensate rights holders for works it had already scanned. The user would see bibliographic information and a few text "snippets" around the search term, unless the publisher had given Google permission to display more. Google offered a possibility of opting out: if rights holders did not want Google to sell or include their books, they just had to say so. This clause results in a transaction cost argument (Gordon 1982): clearing rights to sell digital copies of out-of-print books, one by one, would be prohibitively expensive.

Google could also commercialize copies of the books to individual consumers, license access to a database of millions of out-of-print books, and display ads next to

\footnotetext{
${ }^{1}$ More precisely, US Authors Guild, five US publishers, and the American Association of Publishers.
} 
book contents. Google would pay $63 \%$ of the proceeds to a Book Rights Registry, which would be charged with locating rights holders and paying them for Google's use of their books (Hanratty 2005).

But the settlement was rejected in 2011, considered "not fair, not adequate and not reasonable." Nevertheless, in November 2013, Judge Denny Chin dismissed the Authors Guild's lawsuit against Google, considering Google's action fair.

\subsection{The case for fair use}

As Klein et al. (2002) demonstrate, the main determinant of fair use is whether the use adversely affects the present or future economic value of the copyrighted work. Fair use is an attempt to balance the tension in the purpose and the effects of copyright law (Benhamou and Farchy 2014): creative working requires creators to profit from their work and, reciprocally, advances in science and knowledge demand broad public access to prior works.

In order to appreciate the value effect of Google Books and to decide whether the use qualified as fair, the Judge launched four non-exclusive tests: purpose and character, nature of the copyrighted works, amount and substantiality of portion used and effect of use upon potential market or value. He concluded that nonfictional books are entitled to less protection against a fair use claim than fictional works. Taking into account that about $93 \%$ of the books in Google Books are nonfiction, the question of protection is not crucial. Moreover, Google limits the amount of text it displays in response to a search and does not engage in the direct commercialization of copyrighted works. Even when scans are available, they are not a substitute for books: users do not get access to the whole text free of charge.

The judge insisted on the social benefits of Google Books which allow poorly resourced research libraries to preserve their collections while increasing the efficiency of discovery by providing a new and efficient way for readers and researchers to find books. "Google Books permits humanities scholars to analyze massive amounts of data-a literary record created by a collection of tens of millions of books." 2

Last but not least, Google Books enhances the sale of books to the benefit of copyright holders by helping them to preserve books and offer them new life. This last point reflects the argument stressed by Anderson (2006) in favor of Amazon.

This decision raises deep implications as it leaves the field wide open with regard to the concept of fair use (Samuelson 2010). Taking into account the tension stressed above concerning the purpose and implementation of copyright law, it allocates more importance to dissemination than to protection: Google is supposed to increase search efficiency, to expand access to books for all citizens, including minorities, and to increase knowledge access for institutions, whatever their resource level.

\footnotetext{
${ }^{2}$ The Authors Guild, Inc. v. Google Inc., 1:05-cv-08136-DC, S.D.N.Y. November 14, 2013.
} 


\subsection{A source of expansion for Google}

How can we interpret Google's strategy? By making text-mining possible and more efficient on a large scale, the number of visitors and the competitive quality of the search engine is improved. Therefore, advertising may be more expensive, even if it is not directly linked to Google Books.

In the same movement, by fighting against a monopoly (property rights), the Judge's decision creates another monopoly (Google over a corpus of millions of out-of-print books), at a risk: Google can decide to price reading, and prices of scanned books may rise over time. Moreover, prices may become out of reach for many institutions of education (Darnton 2010).

Finally, while Google Books is presented as a non-profit initiative, it contributes to the economic power of Google and questions the capacity of publishers and retailers to implement a complementary strategy for eBooks.

\section{The case for fair competition}

\subsection{The three price models}

For books and eBooks, three alternative price models exist. Firstly, in the wholesale model, publishers set the price of books and sell them to retailers at a substantial discount. Retailers sell the books to consumers at prices they decide. They pay the other participants of the supply chain (especially the authors), and keep the profitor swallow the loss. They can sell popular books at a significant discount, in order to widen their market share. Secondly, in the agency model, retailers become "agents" through which publishers sell books directly to consumers. The agency model does not allow for discounting; contracts provide publishers with some control over retail prices. Thirdly, in the Resale Price Maintenance or RPM model (fixed book prices), the publisher determines the price at which booksellers sell a book title to consumers (Deneckere et al. 1997). RPM removes the possibility for booksellers to compete on prices. RPM was introduced in France in 1981 and adopted by several European countries. It was extended to eBooks in 2012 in spite of the doubts of the French Competition Authority (Autorité de la concurrence 2010; Simon and De Prato 2012).

From 2007 to 2010, Amazon adopted a wholesale model. In order to launch and capture the eBook market which was still in its infancy, the online retailer discounted best sellers and hawked them for $\$ 9.99$, at a loss. In 2009 , the market share of Amazon for the total trade of books and eBooks reached $19 \%$ (10\% in 2004, source: Institute for publishing Research). In 2010, Apple launched its tablet iPad and publishers negotiated agency contracts. In the Apple "agency model," the publisher determines the retail price and pays a $30 \%$ commission to the retailer. Apple proposes price caps (of \$12.99 and \$14.99) for new releases. Contracts include a "most-favored-nation" clause, which ensures that no e-retailer can set prices below those charged on the Apple iBookstore. This deal was much more convenient for publishers, and the pressure of the book value chain actors led 
Amazon to adopt this contract too. Consequently, prices went up and competition rose in the eBook marketplace: Amazon market share fell from $90 \%$ in 2010 to $60 \%$ in 2012 (source: Publishers Weekly).

In 2012, the Antitrust Division of the US Department of Justice filed a case against Apple and large book publishers, alleging that publishers used agency contracts as a way to coordinate pricing. The department considered that Apple "facilitated a horizontal conspiracy" to eliminate retail price competition. Finally, publishers settled with the DOJ: they would refrain from making deals constraining the ability of retailers to discount, and agency contracts were temporarily prohibited. This settlement led to a new increase in Amazon's market share (67.0 \% in 2013, source: BISG 2013). As in the case of Google, we can stress this paradox: With eBooks, fair competition and free prices reinforce monopolistic position.

\subsection{An illustration of the effects of the quasi-monopolistic position of Amazon}

In May 2014, Amazon was seeking better terms in contract negotiations with Hachette Book Group (HBG owns Grand Central Publishing, Orbit and Little, Brown and many other imprints as well). Amazon intentionally delayed delivery of Hachette books, decided to charge more for books and even launched a campaign to discourage customers from buying books by Hachette, suggesting that buyers might enjoy those of other authors. Many authors signed a letter to Amazon CEO and founder Jeff Bezos asking him to solve the problem without blocking or delaying the sale of books to its customers. On both sides, the stakes were high. Amazon controls a significant part of the book business, which means big publishers cannot survive without it. However, on this occasion, Amazon risked alienating authors. ${ }^{3}$

\section{Concluding remarks}

Both cases bear testimony to a propensity of giants to increase their economic and/ or cultural power (network externalities), without any real counterforce from regulators, thanks to the oligopolistic structure of the eBook market. Therefore, unfair competition seems to be an inherent risk.

Moreover, Amazon and Google are free riders. On the one hand, Google offers texts (or extracts of texts) without financing the publishing and creating process. On the other, Amazon thrives on free riding, which in this case consists of consumers enjoying free of charge services from physical bookshops and making purchases on the Amazon website.

In the case of Amazon, the only way for publishers to fight against the market power of giants is to play one giant against the other.

Should States intervene to maintain fair competition? Some arguments are consistent with this idea. As other cultural goods, books are perceived as being

\footnotetext{
3 After a 6-month dispute, Amazon and Hachette Book Group, USA, have reached a multi-year agreement for eBook and print sales in the USA: HBG will have responsibility for setting the consumer eBook price, but the deal includes financial incentives for Hachette to deliver lower prices.
} 
different from other commodities (Barker and Davies 1966) because of their high cultural value (externality and merit good argument). This point leads us to consider that books and eBooks should not be left to the whims of the market, as illustrated by the cultural diversity argument. One can argue that booksellers need to use the margins on blockbusters to cross-subsidize the riskier submarkets (market-side argument). Others call for the law to help find a balance in the share of profits with authors.

However, governments are rather unable to counterbalance the power of giants. Firstly, giants easily evade taxes as they locate their activities in the most fiscally favorable countries (Ireland and Luxembourg in Europe, etc.). Secondly, they benefit from infinite economies of scale. They are vertically integrated, and their market power allows them to build deals that raise other economic agents against each other.

Generally speaking, one can speculate over what the optimal level of competition in cultural digitized markets should be. This question is open for further research.

Acknowledgments I would like to thank Kathryn Graddy for her help and comments.

\section{References}

Anderson, C. (2006). The long tail. Why the future of business is selling less of more. New York: Hyperion.

Autorité de la concurrence. (2010). Avis relatif à une demande d'avis du ministre de la culture et de la communication portant sur le livre numérique. http://www.autoritedelaconcurrence.fr/user/avisdec. php?numero=09A56. Accessed 28 Dec 2014.

Barker, G. R., \& Davies, R. E. (1966). Books are different: An account of the defense of the net book agreement before the Restrictive Practices Court in 1962. London: Macmillan.

Benghozi, P. J., \& Benhamou, F. (2010). The long tail: Myth or reality? International Journal of Arts Management, 12(3), 43-53.

Benhamou, F. (2014). Le livre à l'heure numérique. Papier, écrans. Vers de nouveaux vagabondages. Paris: Le Seuil.

Benhamou, F., \& Farchy, J. (2014). Droit d'auteur et copyright (3rd ed.). Paris: La Découverte.

BISG. (2013). A Few More Ebook Stats, 2013, http://www.digitalbookworld.com/2013/bisg-report-afew-more-ebook-stats/. Accessed 28 Dec 2014.

Brynjolfsson, E., Yu, J., \& Smith, M. D. (2003). Consumer surplus in the digital economy: Estimating the value of increased product variety at online booksellers. Management Science, 49(11), 1580-1596.

Caves, R. E. (2000). Creative industries. Contracts between art and commerce. Cambridge: Harvard University Press.

Darnton, R. (2010). Apologie du livre. Demain, aujourd'hui, hier. Paris: Gallimard.

David, P. A. (1985). Clio and the economics of QWERTY. American Economic Review, 75(2), 332-337.

Deneckere, R., Marvel, H. P., \& Peck, J. (1997). Demand uncertainty and price maintenance: Markdowns as destructive competition. American Economic Review, 87(4), 619-641.

Dewatripont, M., Ginsburgh, V., Legros, P., Walckiers, A., Devroey, J.P., \& Dujardin, M. et al. (2006). Study on the economic and the technical evolution of the scientific publication market in Europe. Report commissioned by DG-Research. European Commission, January. http://ec.europa.eu/ research/science-society/pdf/scientific-publication-study_en.pdf. Accessed 28 Dec 2014.

Forge, S., \& Blackman, C. (2009). OLEDs and E-PAPER: Their Disruptive Potential for the European Display Industry. IPTS report. ftp.jrc.es/EURdoc/JRC51739.pdf. Accessed 28 Dec 2014.

Gallimard, A. (2007). Rapport de la Mission de réflexion sur la Librairie indépendante. Paris: Ministère de la culture et de la communication.

Gordon, W. J. (1982). Fair use as market failure: A structural and economic analysis of the Betamax Case and its predecessors. Columbia Law Review, 82, 1600-1657. 
Hanratty, E. (2005). Google library: Beyond fair use? Duke Law and Technology Review, 10. http:// scholarship.law.duke.edu/cgi/viewcontent.cgi?article=1130\&context=dltr

Katz, M. L., \& Shapiro, C. (1986). Technology adoption in the presence of network externalities. Journal of Political Economy, 94(4), 822-841.

Klein, B., Lerner, A. V., \& Murphy, K. M. (2002). The economics of copyright "fair use" in a networked world. American Economic Review, 92(2), 205-208.

Manuel, K.M. (2009). The Google Library Project: Is Digitization for Purposes of Online Indexing Fair Use under Copyright Law? Congressional Research Service, R40194, 7-5700. http://fpc.state.gov/ documents/organization/128387.pdf. Accessed 28 Dec 2014.

McCabe, M., \& Snyder, Ch. (2005). Open access and academic journal quality. American Economic Review, 95(2), 453-458.

Merkovski, J. (2013). Burning the page. The e-book revolution and the future of reading. NY: Sourcebooks.

Moreau, F., \& Peltier, S. (2012). Internet and the "Long Tail versus Superstar Effect', debate: Evidence from the French Book Market. Applied Economics Letters, 19, 711-715.

MOTif. (2012). EbookZ, l'offre illégale de livres numériques. http://www.lemotif.fr/fr/etudes-et-donnees/ etudes-du-motif/ebookz/. Accessed 28 Dec 2014.

ParisTech Review. (2011). Which Economic Model for Digital Books? http://www.paristechreview.com/ 2011/10/06/economic-model-digital-books/. Accessed 28 Dec 2014.

Rochet, J. C., \& Tirole, J. (2003). Platform competition in two-sided markets. Journal of the European Economic Association, 1, 990-1029.

Samuelson, P. (2010). "Is the Proposed Google Book Settlement 'Fair'?", 2 AMI: Tijdschrift voor Auteurs, Media \& Informatierecht. http://people.ischool.berkeley.edu/ pam/GBSFair.pdf. Accessed 28 Dec 2014.

Shapiro, C., \& Varian, H. (1998). Information rules: A strategic guide to the network economy. Cambridge: Harvard Business School Press.

Simon, H. A. (1971). Designing organizations for an information-rich world. In M. Greenberger (Ed.), Computers, communication, and the public interest (pp. 40-41). Baltimore: The Johns Hopkins Press.

Simon, J.P., \& De Prato, G. (2012). Statistical, ecosystems and competitiveness analysis of the media and content industries. The Book Publishing Industry, JRC Technical Reports.

Thompson, J. B. (2012). Merchants of culture. Cambridge: Penguin.

Wischenbart, R. (2013). Global eBook Report. http://www.wischenbart.com/upload/Global-EbookReport2013_final03.pdf 